\title{
The Distribution of Power in the Recruitmen of Prospective Head Area by PDI-P in the Election Year 2015 Jember
}

LOGOS

JOURNAL

\section{MIMIN ANWARTINNA}

Government Studies of the Faculty of Economics and Social Sciences (FEIS) Islamic University Raden Rahmat (UNIRA) Malang mimin_anwartinna@uniramalang.ac.id

\begin{abstract}
The distribution of power is still a debate in the party's internal politics, especially in terms of recruitment of candidates for regional elections head. Yet the existence of a clear policy related settings portion of authority between the Centre Party and the party in an area is often the cause of difference of interests and the decision appeared, particularly the matter of flying a candidate head of the region. The implication is unavoidable political dynamics. This paper seeks to analyse thoroughly about the distribution of power in the political candidate recruitment head area in PDI-P Jember. The focus of the writing refers to the moment of the Election Year 2015 Jember. Analysis of peeled through the perspective of the theory of political recruitment and distribution of power. The results of the analysis gave an explanation that is not yet a clear subject control distribution of power in the sphere of internal party candidacy candidate in terms of the head area. This implies the existence of the political dynamics of differences at each level of the process candidacy. When the populist nature of the power distribution then the process candidacy running electorate with a more democratic, more inclusive, as well as the representation of social groups can be more assured. Meanwhile, when the distribution of power are elitist by rising degree of exclusivity of candidacy political interests, opportunities to appear much larger due to the interaction between the candidates with the electorate became more and more intensive.
\end{abstract}

Keywords: Power Distribution; Recruitment of Politics; Elections.

\begin{abstract}
ABSTRAK
Distribusi kuasa masih menjadi perdebata diinternal partai politik. Khususnya dalam rekrutmen calon kepala daerah untuk pilkada. Belum adanya kebijakan yang jelas terkait pengaturan porsi kewenangan antara partai pusat dan partai di daerah seringkali menjadi sebab perbedaan
\end{abstract}


Vol. 1 No.1

March2018

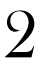

kepentingan -dan keputusan muncul. Khususnya soal pengusungan kandidat calon kepala daerah. Implikasinya adalah dinamika politik tidak dapat dihindari. Tulisan ini berupaya menganalisis secara tuntas mengenai distribusi kuasa dalam rekrutmen politik calon kepala daerah di PDI-P Jember. Fokus tulisan mengacup ada momen Pilkada Jember Tahun 2015. Analisa dikupas melalui prespektif teori rekrutmen politik dan konsep distribusi kekuasaan. Hasil analisa member penjelasan bahwa belum adanya control yang jelas perihal distribusi kekuasaan di lingkup internal partai dalam hal kandidasi calon kepala daerah. Hal iniberimplikasi pada adanya perbedaan dinamika politik disetiap level proses kandidasi. Ketika distribusi kuasa bersifat populism akan proses kandidasi berjalan lebih demokratis dengan selektorat lebih inklusif, serta representasi kelompok sosial dapat lebih terjamin. Sementara, ketika distribusi kuasa bersifat elitis dengan kian naiknya derajat eksklusifitaskan didasi, peluang kepentingan politik untuk muncul jauh lebih besar karena interaksi antara kandidat dengan selektorat menjadi semakin intensif.

Kata Kunci: Distribusi Kuasa; Rekrutmen Politik; Pilkada.

\section{INTRODUCTION}

This paper aims at clarifying the distribution of powers in the process of recruitment of prospective head of area at PDI-P Jember. This analysis is interesting considering the distribution of power in political parties is still in debate, especially when the party faced in recruitment processes of politics. That normative basis in law number 2 of the year 2008 about the political parties, the share of authority between the Centre Party and the party's Chief candidate in the determination of the area of the region is not mentioned explicitly, so it often makes the party in the area is easily intervened politically by the CentreParty.

As long as this distribution of power is more alluded to in the realm of the State and society. In contrast to the distribution of State power are more raw and normative, on the level of the community of people with a particular power source holdings can distribute its powers in more freely. Moreover, the distribution of power in fact did not stop on two domains only. Political parties as actor intermediary did not escape from a similarconcept. 
The distribution of power within the body of a political party is still a debate, especially for the context of the political JOURNAL determination of candidate recruitment head area. This is a concern given the existence of the related rule yet how big a portion or the authority of the Centre Party and the party of the regions in determining candidates for head of the elections. So that it often happens easily in the area of party political intervention by the Centre Party with regard to the decision of the party in recommending candidates for the head of the elections.

In the process of flying a candidate prefect, no wonder if often wishes the party in different areas with the end result a decision Center. Of course as the owner of the arena of democratization in the region, the authorities of the party of regions to determine the prospective candidates. However, because hierarchical bumps into the party, Centre Party remained the superior party capable of pressing the parties in the region to be obedient in every decision of the Centre Party.

A reflection of the power of the tug between the Center and regions such as occurred in Bantul PDI-P when the moment of the elections in 2015. The defeat of the PDI-P is considered as the arrogance of the PDI-P which the party must defeat recommendation cadre with other cadres. This implies a PAC 14 dismissal because the cadres did not approve recommendations of PDI-P Central. It can be seen that the implementation of the party is still strong, though the distribution of the power run, but Centre Party still serves as a key factor in the elections.

Not much different from the above, the unfortunate year 2013 elections colored by the Chairman of the PDI-P DPC hapless reluctantly approve recommendation cadres since the Chairman's wife ran anyway. So that happened was the dismissal of the Chairman of the PDI-P and his wife moved to the bow of the Golkar to keep can nominate them 
Vol. 1 No.1 March2018

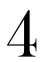

(Anwartinna, 2014). A situation which was later taken over by the Central Party, this shows the side of the elitism party which the owners of power can play a role to restrain the authority owned.

Several more cases showed that the Center Party holds an important role as the political dynamics in the region of the silencer. While this paper focuses on how to actually process the internal distribution of power in the party is in the process of recruitment of prospective head area, more focus on the PDI-P Jember, as well as parts of the reasons the Party decided to recommend candidates who carried. Subsequent analysis attempts to look at the process of distribution of power at every level candidacy and find out if there is a difference in the political situation over the accession process of candidacy in internalparty.

\section{LITERATURE REVIEW}

\section{Distribution of Power}

Power into one arena of struggle in the world political situation, in which it owns with power, one can affect others appropriate interests him. The power is the ability of a person or a group of humans to influence the behavior of others until their behavior into accordance with the wishes and goals of the owner of these powers. For the party, power became a tool to ease the party's interests through common interests. With owned a power, then the party can easily to accommodate the interests of the party become government policy (Budiardjo, 1996).

Power source according to (Budiardjo, 1996) there are from a variety of establishments, from physical violence, position, wealth, confidence and others. When a source has one of these powers, then it can be used to influence others in accordance with the will of the owner of the power. In the context of the political parties,power is often called with a 
hierarchical structure that is attached to it, the other is not because

the party is a political organization that has the power through the structure of the patterns formed. The pattern is then led to the distribution of power or power-sharing.

The distribution of power is the creation of a political system that is able to distribute the power resources evenly to all groups or individuals (Ramlan, 1992). It means that the distribution of power can be used as one way to ease the course of democratization between the parties concerned. During this power closely linked to the identity of the country, where Jhon Locke in (Budiardjo, 1996) alluded to the existence of the separation of powers (separation of powers) as on the concept of political institutions (Executive, legislative and judicial). Then became a division of power (division of powers) are taken to mean that only the vital functions are differentiated according to the nature and turned over to a different body, but for the rest of the cooperation remains necessary for the smooth running of the organization.

There are at least three models of power distribution can be monitored i.e. elite models, model pluralism and populist models (Ramlan, 1992). Gaetano Mosca in (Ramlan, 1992)mentions the elite models are divided into classes which ruled (monopolize power, enjoy the gains) and class that ruled (can be controlled and directed). Model-based cultural interest's pluralist, where power is regarded as the owner of a Contracting Government to the importance of the bridge. Populist model see individual participation will have implications for their social life. Populist model is considered more democratic because it puts the same position on each individual to distribute values on society.

\section{Political Recruitment}

In the context of elections political recruitment was made the moment of selecting party cadres and selecting the best before carried in the election. Political recruitment can also 
Vol. 1 No.1 March2018

6

reflect the faces and the characteristics of the party i.e. like how democratic processes that occur in the internal party. Political recruitment may indicate loci of power(oligarchic or spreads), internal power struggles of a political party (the existence of individuals and factions of the party), the representation of social groups of society, the circulation of elites, determining the face of the party in public spaces, as well as reflect the party type (Pamungkas \& Parlindungan, 2011).

Political recruitment (candidate selection) by (Katz \& Crotty, 2006)meant as individual electoral success in the party. This definition shows that candidate selection is more prioritized for cadres of the party. While the fact of the matter is not closed the possibility, recruitment also involves non- political cadres. Broadly speaking, (Katz \& Crotty, 2006) view of political recruitment process i.e., divided into three stages of certification, nomination and election. The trio is a series of processes that should be undertaken by a candidate who wants to run in the election.

More than that, looking at the candidate selection process as a whole, Katz and Clotty then divide it in two great setups, the method of selection of candidates and the political consequences of candidate selection. The method of selection of the candidates including the offending matter electorate, candidacy, decentralization and voting vs. Rapture. While the political consequences of discussing about participation, representation, competition, responsivities, and intra party democracy.

On candidate selection method, electorate is meant as a party candidate selectors that can come from members of the party or outside it. Electorate is divided according to the degree of inclusion, where the more inclusive so big quantity of electorate, else otherwise. Candidacy is a selection process to choose the best candidate among existing ones. Candidacy 
is also divided into degrees of inclusivism, where the more

inclusive candidacy every person has the right to stand as

candidates. On the contrary, the more exclusive candidacy, only those who meet the requirements can qualify for selection.

Decentralization is meant in two respects, the decentralized territorial and functional. Generally territorial, political process centralized Government to make it easier to ensure representation in the region. From the functional side, the political decentralization undertaken to guarantee the representation or representation of community groups. Voting vs. Rapture are two different candidacy process, where a smaller scale when candidacy or electorate is exclusive, the candidate is usually appointed or appointed. Instead of the larger scale, candidate selection was done through a voting mechanism.

Refer to the idea of (Katz \& Crotty, 2006), the political consequences are understood as the effect of the candidacy process is running. Participation is linked when electorate more inclusive participation of large quantity then, while if the exclusive electorate then the quality of participation is higher. Participation is also linked on the candidates; where in the process of candidacy does not cover the possibility of the existence of "instant member" who brought the party to demonstrate the attitude of the party as the party's credibility than the viewer enhances the quality membership. In other contexts, the representation is used as a medium to regulate conflict and balance of the party. The competition shows the existence of the power incumbent that can affect the process of candidacy, where incumbent is considered political relations got even close to electorate so that it can have an effect on the process of breakouts candidates. Responsivities is the search support activities conducted each candidate and make use of its network for the candidacy process is running. The intraparty democracy can be used as bench marks look at 
Vol. 1 No.1 March2018

8 the internal democratization of the party from participation, responsivities as well as internal party competition.

Two major theories above, distribution of power and the subsequent elaboration in political recruitment in one series to see how the distribution of power in the process of candies in internal party.The candidate selection process hierarchy gives the opportunity analysis are on every level candidacy has the same power distribution or quitedifferent.

\section{RESEARCH METHOD}

This research uses qualitative research methods in which data quality preferred compared to the amount of the data itself, so that the selection of qualitative methods is a step right so that data can be dug in more depth. Confirmed (Creswell, 2009)that qualitative research as an attempt to interpret the understanding of corporate and individual or group deemed to emanate from the human and social problems. This means that qualitative research allows researchers to the existence of the data object's corporate research. Type of this research is a case study of using election year 2015 Jember with PDI-P analysis unit in Jember. Data sources obtained through primary and secondary data. Data collection techniques obtained through interviews, literature studies, and documentation. Technique of data analysis using the concept of (Creswell, 2009)i.e. help give you an idea of the techniques of data analysis starts from doing the transcript data that has been retrieved, doing the process of organize and prepare data for analysis, and finishing reading the data gathered are continued with the coding of data based on the data and descriptions. When the classification has been carried out, the next step is to link the themes or the description of the data with the theory. The last step i.e. interpret the themes and data that has been retrieved. This analysis technique aimed at objective analysis of membagun based on the the oretical concepts that are used. 


\section{The Distribution of Power at Every Level of Recruitment}

PDI-P Jember in this context has been running a recruitment process in accordance with internal policies of the party. Recruitment is important to get a candidate electable and acceptable (Basyar, 2009)in the community. Refer to the applicable rules, the DPC Jember PDI-P has the authority to do the networking process and registration of prospective candidates head area. While the DPP PDI-P has

the authority to filter out candidates that have been processing by DPC.

The PDI-P Jember not only did the recruitment process in the internal party cadres, but also facilitate the prospective of non member of political party to be given space in the nomination of the head of the regions party. It's just that there is a difference of the two processes, in which candidates who come from party cadres through mechanism of networking, while candidates from non member through the registration process. Both the prospective candidate of cadres and cadres, over all will be the candidate collection process boils down to prospective candidates of the head area with are cord meets the completeness of file administration. The candidates are still referred to as prospective candidates because it still needs to be through stage filtering and fur their networking in internal party. The process is to seek out the best among the candidates who have been there before eventually carried on the elections.

According to internal policies in networking, the DPC has two mechanisms i.e. Registration and networking. Networking is the candidate selection process aims to identify potential cadres by involving Executive Board branch or PAC as a party authorized to select candidates. While registration is prospective candidates are applying directly to the party with certain requirements as stated in the rules of the party. 
Its own screening process conducted by the Centre Party as the owner of supreme power in the hierarchical party, so that the results of the decision of the party is the candidate who ultimately can be nominated as a candidate for the head of the region in the elections. Refer to the logic of the hierarchical party, then the next will be described the process of candidacy that also apply are tiered.

The candidacy processoccursin PDI- P Jember comprehensively included with different political dynamics that have emerged. The PAC assisted Twigs as electorate in the grass roots in the normative has discretion in the process of identification of candidates. The identification because the PAC are tasked to help potential candidates raise DPC acceptable and electable to carried on the elections. As it is known that the number of PAC in Jember as much as 31 PAC with each membership of 11 people, meaning there were 341 people electorate that can take part in the process of identifying candidates. That the more active electorate involved in the candidacy process, then the electorate can take a part of her social life changes in the future.

Though they may not all individuals involved active as inclusivism electorate, at least on this level into the arena of a more democratic political participation for the Executive Board of the party to engage in a process of candidacy. Inclusive is electorate in line with the quantity of candidates obtained. According to internal policies of the party, every PAC authorized to propose a maximum of two candidates, meaning that if the entire PAC was involved actively in this process so there are 62 person proper candidates identified. But with some specific political considerations, that number may be too large to be processed in the candidacy in the DPC and takes longer to efficiency of mapping the candidate, though not close the possibility that number could have been realized. 
In territorial, distribution of power given to the PAC to trawl the prospective candidate is as a reflection of political decentralization in the territorial concept. Indirectly DPC using electorate the PAC to ensure representation in the area with much more authority to capture PAC candidates. The implementation of this process characterizes that PDI-P attempts to perform the process in a democratic candidacy in the basic level. But it could just be the democratization of candidacy will undergo changes over the rising degree of exclusivity.

DPC level selection into the next after PAC managed to attract prospective candidates. The difference in the political situation began to present when the degree of exclusivity of rising though still in the level region. The exclusivity can be seen from the increase in the quantity of electorate, candidacy, political decentralization process and candidate selection mechanism which is different from the process of candidate selection by the PAC.

If a PAC electorate participation level is open to members of the larger Branches and members of the PAC, then electorate in contrast to the DPC. Electorate structural sysop-Member DP (Kholiq \& Wibowo, 2016).It can be found alongside members of the DPC PDI-P Jember amounted to 19 people, meaning that the quantity electorate is becoming increasingly limited. On candidacy in functional decentralization, DPC level a bit overlooked given the electorate only on duty receive applicants from nonmember of political party, unlike networking PAC is more able to determine the representation of social groups in the community through the selected candidate. The implication is that candidates who are screened in this be limited to those who nominate or register to the party alone.

Candidacy in level DPC is done through the mechanism of the deliberations in the Conference forum branch. In the 
process, DPC electorate do candidacy with prospective efficiency of mapping mechanism, perform the SWOT analys is against any candidates who had registered before presented to members of the party. At the forum, the elitism electorate began to appear when the dominance of the power of the party's Executive Board also served as electorate candidacy is capable of affecting the existence of the candidate and the candidate's breakouts in a discussion forum candidacy, certainly in the position is a candidate who has a political affinity with electorateDPC.

Refer to the data candidacy in PDI-P candidate composition of Jember, up to the level of DPC considered yet balanced. It is because the quantity of candidates in fact dominated by candidates from non-part of the political party. While the party that should have a duty to carry the cadres in the election processes, at this point tend to improve the quality of cadres ignored due to certain political considerations. Minor cadres who netted DPC can be meant in some ways like the pragmatism of the party, the failure of the party cadre recruitment in the internal crisis of confidence, or failure of the party cadres in the Government.

In this case electorate DPC as treating equally between candidates from a non-political party's members with the candidate who was born and raised out of the party. Whereas cadres is a properly prepared by the party to put forward for election, however in this case the position of cadres should be kicked out by the interests of the party. If such situation occurs continuously, it is not impossible-activist party activists will be eroded.

DPD becomes the next selection level after a candidate passes the political process in the DPC. The fundamental difference to observe elitism power in electorate DPD with electorate previously set on the object of a hierarchical structure of the party. If DPC electorate power to rule electorate in 
PAC as well as both have authority to conduct the different candidates, candidate networking thing with electorate inthe DPD. In addition to not having the authority to select candidates, electorate DPD is in position as the party governed as well as those who are ruled. Electorate DPD as a party can be ruled by the DPP, on the other hand electorate DPC DPD has the right to rule based on instructions from the DPP.

In the capacity of being facilitator candidacy electorate, DPD also has authority to help the selection process candidacy. It's just that the process still refer to electorate instructions of the DPP. Then comprehensively DPD electorate position just as the bridge process candidacy of DPC before heading level candidacy in the DPP, because hierarchical selection process candidates must pass in the DPD in advance. Despite acting as facilitator, candidacy selection process remains running in the DPD levels.

At the level of the DPD, the exclusivity of candidacy occurred. Exclusive in terms of quantity of candidates will be filtered and the quality of candidates will also be filtered again. If in candidacy in level DPC only as doing networking candidates, then at the level of the DPD is not all candidates who qualify will be netted as a potential candidate for the head of the region because the function electorate in the DPD is in addition to seeing the quality of the candidates also filter candidates based on those electable in the society and acceptable victory party can be achieved at the moment of the elections.

The function of DPD becomes a mirror of the political decentralization of implementation, while functionally, decentralization is considered not running considering the DPD does not have the authority to select candidates, but select their candidate based on instruction from the DPP. So indirectly the candidate views not based representation of social groups in society, but in terms of the eligibility of the candidates personally are worth to qualify or not. 


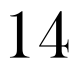

The DPP became the final candidacy level as well as the Summit of exclusivity of all aspects of the candidacy party started from the increasingly exclusive electorate process candidacy more strictly, as well as the final appointment of candidates for elections in carried. That the exclusivity of the selection in the DPP could be precisely the political rift to the parties concerned so that the candidate obtained breakouts. More than that the DPP is a party as holding the legality of candidacy, so that each candidate will certainly strive to seize the party's recommendation.

Conceivably if electorate is a group of DPP party members are very exclusive and have a standard high enough for the assessment of the candidates. One thing that causes the high standard electorate the DPP is considering the DPP is the party that holds the authority to determine the end result of the process of candidacy and became the deciding who the candidate is nominated as the head of a decent area by PDI-P. So electorate the exclusivity to be one basis for a tight selection process at this level.

Power electorate of the DPP became the highest authority in the process of candidacy considering there is no longer a hierarchical structure above the DPP party. It then makes the electorate the DPP can determine the direction of party politics in the process of candidacy. Party political considerations poured electorate DPP through the political process is being done. In addition, the General Chairman of the PDI-P became one important figure of the electorate of the DPP. Electorate activities that all DPP boils down to the Chairman'sapproval.

Refer to the data at least from the candidates who entered the networking of PAC and the DPC, and after going through the process of candidacy in each level, only filterable 13 candidates only. The number of naturally aligned with the level of exclusivity of the candidacy process. For some candidates who had departed from the basic networking DPC 
and PAC, electorate relations with the DPP very much its distance

because of restrictions the central party hierarchy and structure of JOURNAL the region. But for some other candidates who have previously had a political affinity with the DPP, electorate candidacy moment in the DPP would certainly be the event prove the extent to which candidates can struggle to seize the party breakouts.

With its exclusive candidacy that is in the DPP selection mechanism, then breakouts candidates are also very different. If in the scope of a more inclusive as in DPC is done through the mechanism of deliberation, then on the level of DPP candidate determination is done by way of appointment. The results of this became the end point for the party that candidates who qualify the candidate the DPP's recommendation will be carried in the elections.

\section{The Implications of the Process of Candidacy}

The explanation above can be identifiers that in each level selection candidacy had a number of differences, such as the distribution of power on populist level PAC and elitism the power of the present candidacy. These differences have implications for further participation, representation on the situation, competition, responsivities as well as intra party democracy.

The process of candidacy in PAC level can be categorized as candidacy the most democratic of the level candidacy. It is a reference from a larger amount of electorate as well as inclusivism candidacy. The magnitude of electorate indicates that any member of the electorate can engage actively in networking candidates. The liveliness proves that every electorate has the same position and has the right to determine the political change that will be received in the future.

The rise in the degree of exclusivity of candidacy in DPC presents the phenomenon of the emergence of thebroker 


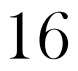

(Realtor political) opportunists who exploit the uncertainty to financial fields as party recommendations for them. In this case the presence of the broker becomes a form of responsivities candidates are vying to seize the party's recommendations by making use of the network. On the other hand, the broker also has the significance behind the support on the candidate. Broker present each candidacies level considering the higher level candidacy then need brokerwith greater political power as well.

The rise in the degree of exclusivity of candidacy is directly proportional to the more discipline candidates for the contested recommendation breakouts. Especially the interaction with electorate candidates are becoming increasingly intensified because of the increasingly limited quantity both. So the interaction between candidates and electorate considered the fight arena of interest. The candidates will wear a political strategy in such a way that electorate prioritized recommendations for her party breakouts, including holding transactional politics. On the other hand, did not close the possibility that this interest arena utilized by new people i.e. bypass the political process by leveraging existing transactional processes. These opportunities are wide open for candidates of non-member of political parties because it is considered more sett led financially.

The presence of top cadres to non-transactional process it further implicates the presence of cadres at the instant. The intent is that candidates who did not follow the process of candidacy of the basic networking PAC or DPC but suddenly can be the candidate for the candidate's head area. What's the instant cadres eventually elected by the DPP as the final candidate for involvement carried. The appearance of this instant cadres proves that the DPP became the arena of interest for each party to seize power by means of a race to seize the party's recommendations first. 
Overall, all political possibilities can occur at the level of the DPP included choosing candidates even before signing-in candidacy. It is assumed that the implementation of the party is still so thick in PDI-p. That as owner of the legality of a candidacy, the DPP has the supreme power to determine the direction of a political party. Though a final decision on the party's political turmoil brings up is not uncommon in the area, but also in the regions party could not do more because it is limited by the structure of the hierarchy and numerous internal party rules.

Political intervention is rarely not show up due to internal conflicts of interest in the party. What's the real Centre party elite is not directly involved in understanding the situation of the political situation in the region is thus more influential in terms of policy making for the party in the region. So between the Centre Party and a party in the area often opposing interests.

\section{CONCLUSION}

Normative basis, there has not been a clear control of the associated distribution of power between the Centre Party with the party in the region in the process of candidate selection. This led to the distinction of the political dynamics of each level candidacy. More than that that attitude of electorate in each level candidacy ends up being freer because of the lack ofcontrol.

Different power distribution model in each level implies a product candidacy. When the distribution power of populist nature implies a process of candidacy electorate with a more democratic, more inclusive, as well as the representation of social groups can be more assured. Meanwhile, when the distribution of power are elitist by rising degree of exclusivity of candidacy political interests, opportunities to appear much larger. 
Vol. 1 No.1 March2018

18

With regard to the process of recruitment in PDI-P Jember, territorial decentralization runs with proven exerts authority DPC to trawl the prospective candidates. Functionally, candidacy in PAC level more guarantees the representation of social groups in society, while at the level of a representative because the limitations experienced DPC DP Con duty receive applicants from non-political party's members, in contrast with the more generous PAC determine the candidate through the process of networking.

Candidate selection in PAC level have a populist power distribution model, so it can better ensure there presentation of social groups in society. At the level of the DPC, the exclusivity of distribution appear to be starting when power is more elitist. Seen from the existence of the dominance of the power of the party's influential structural sysop against breakouts of prospective candidates concerned. At the level of the DPD is a little different, though the process candidiasis more exclusive but act more as a facilitator of DPD in candidate selection in internal party. On the level of DPP, the distribution of power is increasingly seen elitist given the quantity electorate is more exclusive than the previous level. At this level apply candidate selection with the mechanism of appointment or appointment.The more elitist model of distribution power, then it will generate a candidacy process and product candidates are increasingly exclusive. 


\section{REFERENCE}

Anwartinna, M. (2014). Kemenangan Anton-Sutiaji (Aji) Dalam Pemilihan Walikota (Pilwali) Kota Malang Tahun 2013. Jurnal Mahasiswa Ilmu Pemerintahan, 1(1).

Basyar, M. H. (2009). Minoritas Muslim Bali: Di Gianyar dan Tabanan (Vol. 2): Kerjasama Lembaga Ilmu Pengetahuan Indonesia dan Kementerian Pendidikan ....

Budiardjo, M. (1996). Partisipasi dan Proses Politik: Jakarta: Gramedia.

Creswell, J. W. (2009). Mapping the field of mixed methods research: SAGE Publications Sage CA: Los Angeles, CA.

Katz, R. S., \& Crotty, W. J. (2006). Handbook of party politics: Sage.

Kholiq, M. A., \& Wibowo, A. (2016). Penerapan Teori Tujuan Pemidanaan dalam Perkara Kekerasan terhadap Perempuan: Studi Putusan Hakim. Jurnal Hukum IUS QUIA IUSTUM, 23(2), 186-205.

Pamungkas, S., \& Parlindungan, U. (2011). Partai politik: teori dan praktik di Indonesia: Institute for Democracy and Welfarism.

Ramlan, S. (1992). Memahami Ilmu Politik: Grasindo. 